\title{
Hepatoprotective and Antioxidant Effect of Mangifera Indica Leaf Extracts against Mercuric Chloride- induced Liver Toxicity in Mice
}

\author{
${ }^{1}$ Muthupillai Karuppanan, ${ }^{2}$ Manigandan Krishnan, ${ }^{3}$ Pavankumar Padarthi, ${ }^{4}$ Elangovan Namasivayam
}

\begin{abstract}
Background: To explore the antioxidant and hepatoprotective effect of ethanolic Mangifera indica (EMI) and methanolic Mangifera indica (MMI) leaf extracts in mercuric chloride $\left(\mathrm{HgCl}_{2}\right)$ induced toxicity in Swiss albino mice.
\end{abstract}

Materials and methods: Toxicity in mice was induced with $\mathrm{HgCl}_{2}(5.0 \mathrm{mg} / \mathrm{kg}$, i.p. $)$, followed by oral intervention with EMI and MMl extracts (25 mg and $50 \mathrm{mg} / \mathrm{kg}$. body wt.) for 30 days.

\begin{abstract}
Results and discussion: The extent of liver damage was assessed from the extents of histopathological, morphological, antioxidant and liver enzymes. Mercuric chloride-induced mice showed an increased cellular damage whereas leaf extracts of EMI and MMI-treated mice showed recovery of damaged hepatocytes. Mercuric chloride intoxicated mice exhibited a significant $(p<0.05)$ elevation in the liver enzymes (Aspartate amino transferase and Alanine amino transferase) and gradual decline in the cellular radical scavenging enzyme levels (Catalase, Glutathione-s-transferase and Glutathione peroxidase. The combined treatment with EMI and MMI leaf extracts significantly $(p<0.05)$ reversed these parameters. However, the effects of MMI leaf extract $(50 \mathrm{mg} / \mathrm{kg})$ were superior to those of EMI- treated mice possibly due to its potent radical scavenging property. These results suggest that oral supplementation of Mangifera indica extract remarkably reduces hepatotoxicity in mice possibly through its antioxidant potentials.
\end{abstract}

Keywords: Mangifera indica, Mercuric chloride, Free radicals, Liver enzymes, Antioxidant.

How to cite this article: Karuppanan M, Krishnan M, Padarthi P, Namasivayam E. Hepatoprotective and Antioxidant Effect of Mangifera Indica Leaf Extracts against Mercuric Chloride-induced Liver Toxicity in Mice. Euroasian J Hepato-Gastroenterol 2014;4(1):18-24.

Source of support: Nil

Conflict of interest: None

\section{INTRODUCTION}

Mercury (Hg), a toxic environmental pollutant, ${ }^{1}$ elicits both acute and chronic liver injury. ${ }^{2}$ Exposure to inorganic mercury can form a complex with thiol group (R-SH) and firmly causes tissue damage, alterations in transcriptional factors and other pathological disorders. ${ }^{3}$ Liver is the prime target for mercury toxicity due to its metabolic activities. Earlier reports suggest that $\mathrm{Hg}^{2+}$ and $\mathrm{Cl}^{-}$are formed as a result of metabolic activation of $\mathrm{HgCl}_{2}$, which can promote lipid peroxidation, tissue injury and DNA damage due to production of reactive oxygen species (ROS), ${ }^{4}$ along with significant decrease of antioxidant scavenging enzymes such as catalase alase, glutathione-s-transferase, and glutathione peroxidise. Earlier studies predict that antioxidants play a prime role to counteract the adverse effects of metabolic free radical products. ${ }^{5}$ Hence, plant-based remedies may provide a protection against mercury-induced toxicity with fewer side effects. Herbal plant represents a quest of unknown metabolites; analysis of those active metabolites is in need for the prevention and treatment of several chronic diseases.

Mangifera indica (MI) Linn is one of the prevalent tropical plants widely used in Indian ayurvedic medicine. ${ }^{6} \mathrm{MI}$ is traditionally used for the treatment of diabetes, ${ }^{7}$ hepatoprotecitve, ${ }^{8}$ radioprotective, ${ }^{9}$ cell migration activity, ${ }^{10}$ antidiarrheal, ${ }^{11}$ anticancer activity, ${ }^{12}$ and antimicrobial activity. ${ }^{13}$ However, heavy metal toxicity of MI leaf extract has not yet documented. In this study, we investigated the possible

\footnotetext{
${ }^{1-4}$ Department of Biotechnology, Periyar University, Salem, Tamil Nadu, India
}

Address reprint requests to: Elangovan Namasivayam, Assistant Professor, Department of Biotechnology, Periyar University, Salem Tamil Nadu, India, Phone: 914272441260, e-mail: elangovannn@gmail.com 
hepatoprotective efficacy of EMI and MMI leaf extracts against mercuric chloride-induced oxidative stress in mice.

\section{MATERIALS AND METHODS}

\section{Chemicals}

Mercuric chloride, L-aspartic acid, L-alanine, 1, 1-Diphenyl2-picrylhydrazyl (DPPH), 2, 4-dinitrophenylhydrazine (DNPH), 5, 5 dithiobis (2-nitrobenzoic acid) (DTNB), reduced glutathione, 1-chloro-2, 4-dinitrobenzene (CDNB), sodium azide, trichloroacetic acid (TCA), O-dianisidine, hydrogen peroxide $\left(\mathrm{H}_{2} \mathrm{O}_{2}\right)$, ethylene diamine tetraacetic acid (EDTA), hemotoxylin and eosin were purchased from Sigma Chemical Co. St. Louis, MO, USA. All chemicals are of analytical grade.

\section{Animals}

Adult male Swiss albino mice (4-6 weeks, weighing 22$25 \mathrm{gm}$ ) were purchased and housed at Central Animal Facility, Periyar University, Salem, Tamil Nadu, India under controlled conditions (12 hours day-night cycle), temperature $\left(25 \pm 2{ }^{\circ} \mathrm{C}\right)$ and relative humidity $(45 \pm 5 \%)$. Mice were caged in polypropylene cages and fed with a commercial pelleted food and tap water ad libitum. The study was conducted after obtaining institutional animal ethical committee clearance (1085/ac/07/PU-IAEC 2011/01).

\section{Plant Material}

MI Linn leaves were collected from in and around Salem district. The plant was identified and a voucher specimen (PU/BT/Mangifera indica. Linn/ S. No. 011/2010) was stored in the herbarium of Department of Biotechnology, Periyar University. The leaves were washed, shade dried, powdered and extraction was carried out using methanol and ethanol in soxhlet apparatus for 6 hours. The extract was concentrated to dryness by using rotary evaporator at 40 to $50^{\circ} \mathrm{C}$ under reduced pressure.

\section{Evaluation of Plant Radical Scavenging Activity}

The ability of MI leaf extracts to scavenge 1, 1-Diphenyl-2picrylhydrazyl (DPPH) radical was assayed by the method of Liyana-Pathiranan. ${ }^{14}$ The percent (\%) inhibition was calculated by the following equation: DPPH radical $(\%)=$ $\left[\left(\mathrm{Abs}-\right.\right.$ control- $\left.\mathrm{Abs}_{\text {sample }}\right) /\left(\mathrm{Abs}_{\text {control }}\right] \times 100$.

\section{Experimental Design}

A total of 36 mice were divided into six experimental groups $(n=6)$ were shown in Table 1 . The experiment was terminated at the end of 31 st day and all the animals were sacrificed under anesthesia. Liver tissues were removed, rinsed in ice cold saline and immersed in $10 \%(\mathrm{v} / \mathrm{v})$ formalin for histological examination and the rest of the liver tissues was homogenized with $10 \%(\mathrm{w} / \mathrm{v})$ of ice cold potassium phosphate buffer ( $\mathrm{pH} 7.4$ ) and centrifuged at 12,000 gm for 20 minutes at $4{ }^{\circ} \mathrm{C}$. The supernatant was stored at $-20^{\circ} \mathrm{C}$ for biochemical analysis.

\section{Biochemical Analysis}

All the enzyme levels in tissue homogenate were measured spectrometrically (Systronics-2203, India Pvt. Ltd. The liver enzymes aspartate amino transferase (EC 2.6.1.1) and alanine amino transferase (EC 2.6.1.2) in tissue homogenate were assessed by the method of Bergmeyer and Bernt. ${ }^{15}$ The activities of both enzymes were expressed in $\mathrm{U} / \mathrm{min} /$ $\mathrm{mg}$ of protein. The protein concentration was measured by the method of Lowry et al. ${ }^{16}$ The antioxidant enzymes glutathione peroxidase (EC 1.11.1.9) catalyzed the oxidation of NADPH coupled with reduced glutathione at $420 \mathrm{~nm}$. The enzyme activity was expressed as $\mathrm{n}$ moles of glutathione oxidized $/ \mathrm{min} / \mathrm{ml} /$ of enzyme, ${ }^{17}$ glutathione S-transferase (EC 2.5.1.18) was performed as described by Habig et al ${ }^{18}$ is using 1-chloro-2,4-dinitrobenzene as substrate and catalase (EC 2.3.1.28) was measured by decrease in $\mathrm{H}_{2} \mathrm{O}_{2}$ reduction at $620 \mathrm{~nm}$. The enzyme activity was expressed in $\mu$ moles of $\mathrm{H}_{2} \mathrm{O}_{2}$ consumed/units/mg of protein. ${ }^{19}$

Table 1: Treatment schedule

\begin{tabular}{|c|c|}
\hline Groups & Route of administration \\
\hline Group I-Control & $0.9 \%(w / v)$ Saline orally for 30 days \\
\hline Group II- $\mathrm{HgCl}_{2}$ treatment & Intraperitoneal induction of $\mathrm{HgCl}_{2}(5.0 \mathrm{mg} / \mathrm{kg} \mathrm{b}$. wt. in $0.9 \%$ saline $)$ for 30 days \\
\hline Group III- $\mathrm{HgCl}_{2}+25 \mathrm{mg} / \mathrm{kg}$ EMI extract treatment & $\begin{array}{l}\mathrm{HgCl}_{2} \text { as prescribed in group II followed by aqueous suspension of EMI extract, } \\
\text { orally up to } 30 \text { days }\end{array}$ \\
\hline Group IV- $\mathrm{HgCl}_{2}+50 \mathrm{mg} / \mathrm{kg}$ EMI extract treatment & $\begin{array}{l}\mathrm{HgCl}_{2} \text { as stipulated in group II followed by aqueous suspension of EMI extract, } \\
\text { orally for the entire period }\end{array}$ \\
\hline Group V- $\mathrm{HgCl}_{2}+25 \mathrm{mg} / \mathrm{kg} \mathrm{MMl} \mathrm{extract} \mathrm{treatment}$ & $\begin{array}{l}\mathrm{HgCl}_{2} \text { as mentioned in group II followed by oral administration of aqueous } \mathrm{MMI} \\
\text { extracts for } 30 \text { days }\end{array}$ \\
\hline Group VI- $\mathrm{HgCl}_{2}+50 \mathrm{mg} / \mathrm{kg} \mathrm{MMl} \mathrm{extract} \mathrm{treatment}$ & $\begin{array}{l}\mathrm{HgCl}_{2} \text { as stated in group II followed by oral administration of aqueous MMI } \\
\text { extracts for } 30 \text { days }\end{array}$ \\
\hline
\end{tabular}




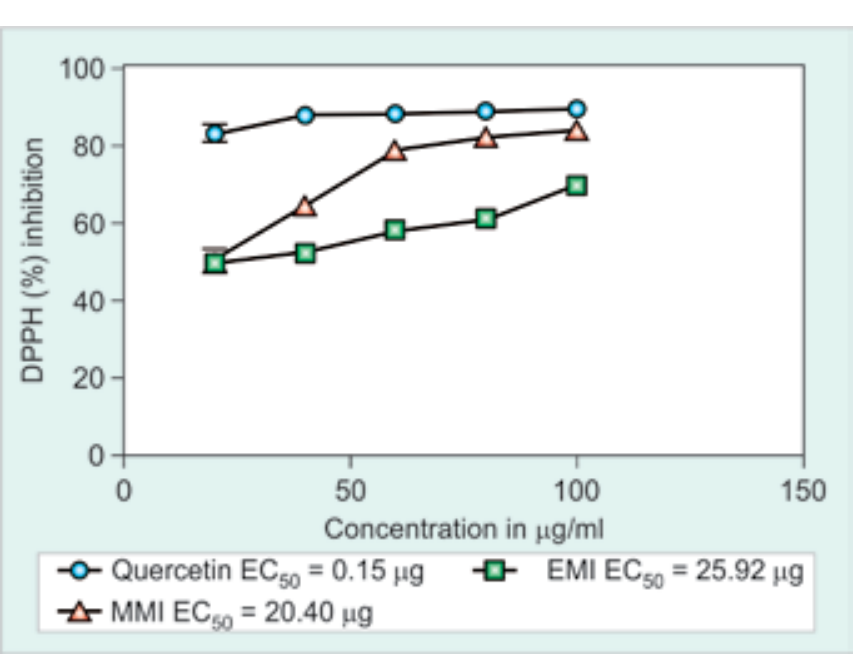

Fig. 1: DPPH radical scavenging activity of ethanolic and methanolic Mangifera indica plant extracts compared with quercetin. The percentage inhibition was plotted against concentration of the sample and the $\mathrm{IC}_{50}$ values of both extract are expressed in $\mu \mathrm{g} / \mathrm{ml}$

\section{Histological Studies}

A segment of the liver tissues was fixed in $10 \%$ formalin solution for 24 to 48 hours and dehydrated in descending alcohol concentration for 12 hours. Tissues were embedded in paraffin wax for 2 hours, sectioned in microtome at $6.0 \mu \mathrm{m}$ size and then deparaffinized under xylene for 2 hours. The sections were stained with hemotoxylin and eosin and the slides were viewed under light microscope [Magnus MLXi, Olympus, India Pvt. Ltd] for histological changes.

\section{STATISTICAL ANALYSIS}

All statistical analysis was conducted using one-way analysis of variance with Dunnett's posttest using SPSS version 16.0. The value expressed as Mean \pm SEM, $p$-value $<0.05$ was considered as statistically significant.

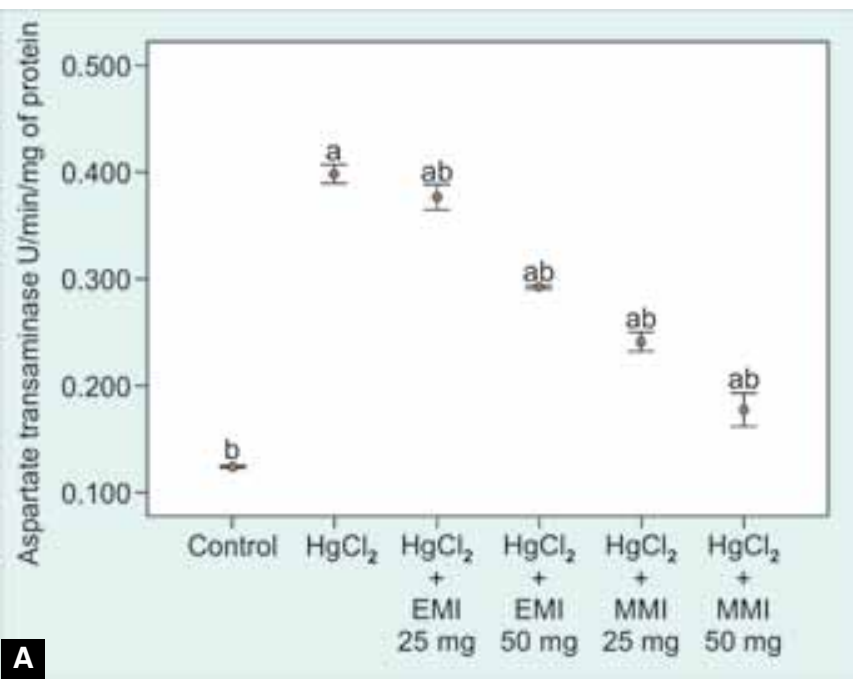

\section{RESULTS}

\section{Biochemical Observations}

The radical scavenging activity of ethanol and methanol MI extracts, compared with standard was shown in Figure 1. The methanol extract produced $50 \%$ of inhibition activity $\left(\mathrm{IC}_{50}\right)$ at $20.40 \mu \mathrm{g} / \mathrm{ml}$ concentration, while the ethanol extract produced $50 \%$ radical scavenging inhibition at $25.92 \mu \mathrm{g} / \mathrm{ml}$ concentration. This result suggests that methanol extract exhibits significant $\mathrm{EC}_{50}$ range at minimum concentration than ethanol extract. All the animals were survived at the entire study period. The average body and liver weight in all groups were shown in Table 2. Mercuric chloride treated group shows a significant $(p<0.01)$ decline in mean of final body and liver weight when compared with control group. Administration of plant extracts significantly $(p<0.01)$ recovered the mean of final body and liver weight, when compared to the intoxicated group. The activities of aspartate transaminase, alanine transaminase, glutathione peroxidase, glutathione s-transferase and catalase levels in liver of control and experimental groups were shown in the Figures 2 and 3. A significant elevation $(p<0.05)$ in liver marker enzymes aspartate transaminase and alanine transaminase levels was observed in $\mathrm{HgCl}_{2}$ alone intoxicated mice with respect to control. But, treatment with EMI and MMI leaf extracts with $\mathrm{HgCl}_{2}$ elicits a significant decline $(\mathrm{p}<0.05)$ in tissue aspartate transaminase and alanine transaminase levels with respect to $\mathrm{HgCl}_{2}$ mice (see Figs 2 and 3). However, MMI extract possesses maximum quenching effect beyond the homeostasis levels.

The antioxidant enzyme (catalase, glutathione peroxidase and glutathione s-transferase) levels in hepatic tissue homogenate of mice in control and experimental groups were shown in the Figures 3A to C. Glutathione s-transferase,

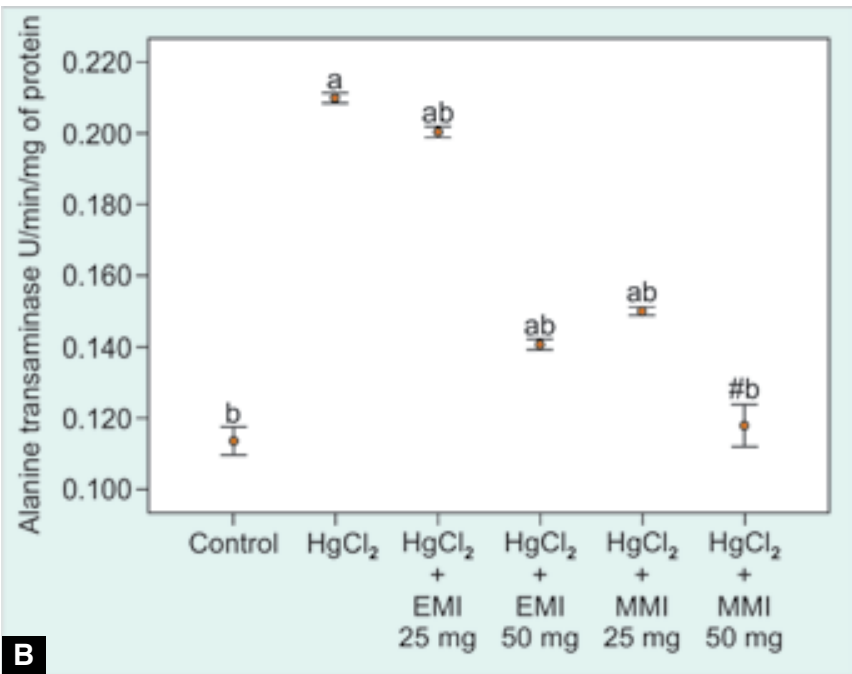

Figs 2A and B: Effect of Mangifera indica leaf extracts on liver marker enzymes (A) Aspartate transaminase and (B) Alanine transaminase levels in tissue of control and experimental mice. Values are expressed as mean \pm SEM for six mice in each group, Dunnett's, values are statistically significant at ${ }^{a} p<0.05$ vs control group; ${ }^{b} p<0.05 v s \mathrm{HgCl}_{2}$ group and ${ }^{\#}$ nonsignificant vs control group 

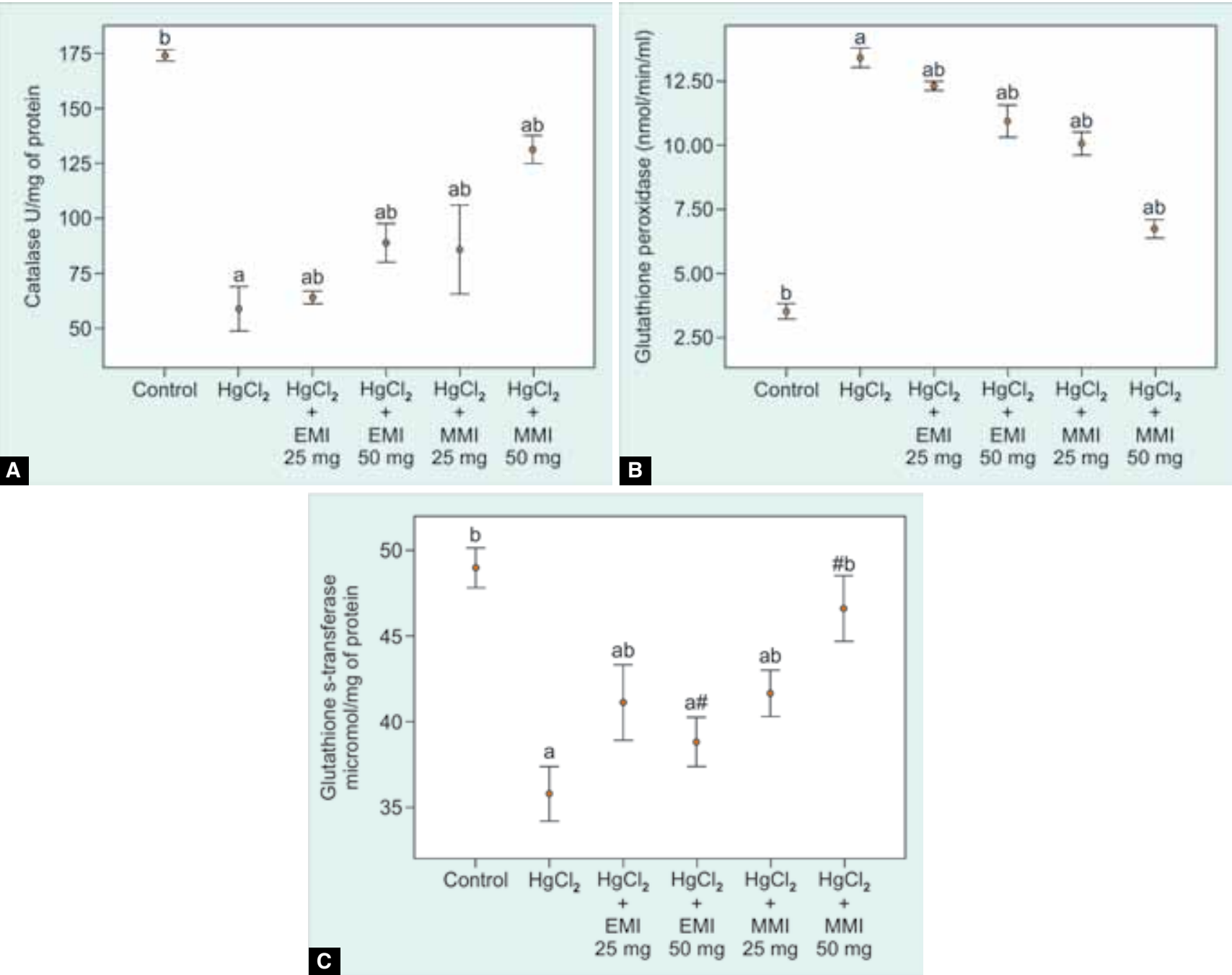

Figs 3A to C: Dose-dependent effect of both ethanolic and methanolic fractions of Mangifera indica leaf extracts on (A) Catalase, (B) Glutathione peroxidase and (C) Glutathione s-transferase levels against $\mathrm{HgCl}_{2}$-induced hepatotoxicity in mice. Values are expressed as mean \pm SEM for six mice in each group, values are statistically significant at ${ }^{a} p<0.05$ as compared with control group, ${ }^{b} p<0.05$ vs as compared with $\mathrm{HgCl}_{2}$ group and ${ }^{\#}$ nonsignificant vs control and $\mathrm{HgCl}_{2}$ groups

a cytosolic antioxidant belongs to an isozyme family, involved in scavenging the cellular reactive oxygen species (ROS). The enzyme level was significantly $(\mathrm{p}<0.05)$ reduced in $\mathrm{HgCl}_{2}$ treated mice with respect to control mice. When compared to $\mathrm{HgCl}_{2}$ group, a significant $(\mathrm{p}<0.05)$ elevation in glutathione s-transferase was observed in MI extract administered groups (Fig. 3C). The levels of glutathione peroxidase and catalase are involved in eliminating the proformed $\mathrm{H}_{2} \mathrm{O}_{2}$ and superoxide anion. When compared with the control group, $\mathrm{HgCl}_{2}$-treated group caused significant $(\mathrm{p}<0.05)$ reduction in glutathione peroxidase and catalase levels. However, EMI and MMI leaf extracts-treated group showed a significant variation in these enzyme levels (Figs 3A and B).

Table 2: Effect of EMI and MMI leaf extracts on body weight, liver weight and relative liver weight of mice liver segment in $\mathrm{HgCl}_{2}$-induced liver toxicity

\begin{tabular}{|c|c|c|c|c|c|c|}
\hline \multirow[t]{2}{*}{ Parameters } & \multirow[t]{2}{*}{ Control } & \multirow[t]{2}{*}{$5.0 \mathrm{mg} \mathrm{HgCl}_{2}$} & \multicolumn{2}{|c|}{$\mathrm{EMI}+\mathrm{HgCl}_{2}$} & \multicolumn{2}{|c|}{$\mathrm{MMI}+\mathrm{HgCl}_{2}$} \\
\hline & & & $25 \mathrm{mg}+5.0 \mathrm{mg}$ & $50 \mathrm{mg}+5.0 \mathrm{mg}$ & $25 \mathrm{mg}+5.0 \mathrm{mg}$ & $50 \mathrm{mg}+5.0 \mathrm{mg}$ \\
\hline Day $1^{\text {st }}$ body weight $(\mathrm{g})$ & $22.5 \pm 0.54$ & $22.83 \pm 0.75$ & $22.83 \pm 0.75$ & $23 \pm 0.89$ & $22.66 \pm 0.81$ & $22.83 \pm 0.7528$ \\
\hline Day $15^{\text {th }}$ body weight $(\mathrm{g})$ & $23.8 \pm 0.60$ & $22.33 \pm 0.60$ & $22.26 \pm 0.65$ & $22.18 \pm 0.51$ & $22.15 \pm 0.32$ & $23.16 \pm 0.71$ \\
\hline Day $30^{\text {th }}$ body weight $(\mathrm{g})$ & $24.5 \pm 0.37^{b}$ & $20.91 \pm 0.44^{a}$ & $22.4 \pm 0.54^{\mathrm{ab}}$ & $22.46 \pm 0.26^{\star \mathrm{b}}$ & $22.46 \pm 0.15^{\mathrm{ab}}$ & $22.67 \pm 0.24^{\# \mathrm{~b}}$ \\
\hline Liver weight $(\mathrm{g})$ & $1.38 \pm 0.05^{d}$ & $1.24 \pm 0.02^{c}$ & $1.3 \pm 0.01^{\mathrm{c}^{*}}$ & $1.31 \pm 0.02^{\mathrm{cd}}$ & $1.317 \pm 0.02^{\mathrm{cd}}$ & $1.33 \pm 0.01^{\# d}$ \\
\hline $\begin{array}{l}\text { Relative liver weight } \\
\text { (g/100 } \mathrm{g} \text { body weight) }\end{array}$ & $5.69 \pm 0.16^{*}$ & $5.93 \pm 0.19$ & $5.77 \pm 0.17$ & $5.77 \pm 0.08$ & $5.52 \pm 0.07$ & $5.73 \pm 0.08$ \\
\hline
\end{tabular}

Data are analyzed by one-way analysis of variance followed by Dunnett's test for six mice in each group. ${ }^{a, c} p<0.01$ and ${ }^{*} p<0.05$ as compared with control group; " nonsignificant $v s$ control group; ${ }^{b}, \mathrm{~d}<0.01$ as compared with $\mathrm{HgCl}_{2}$ alone-induced group 


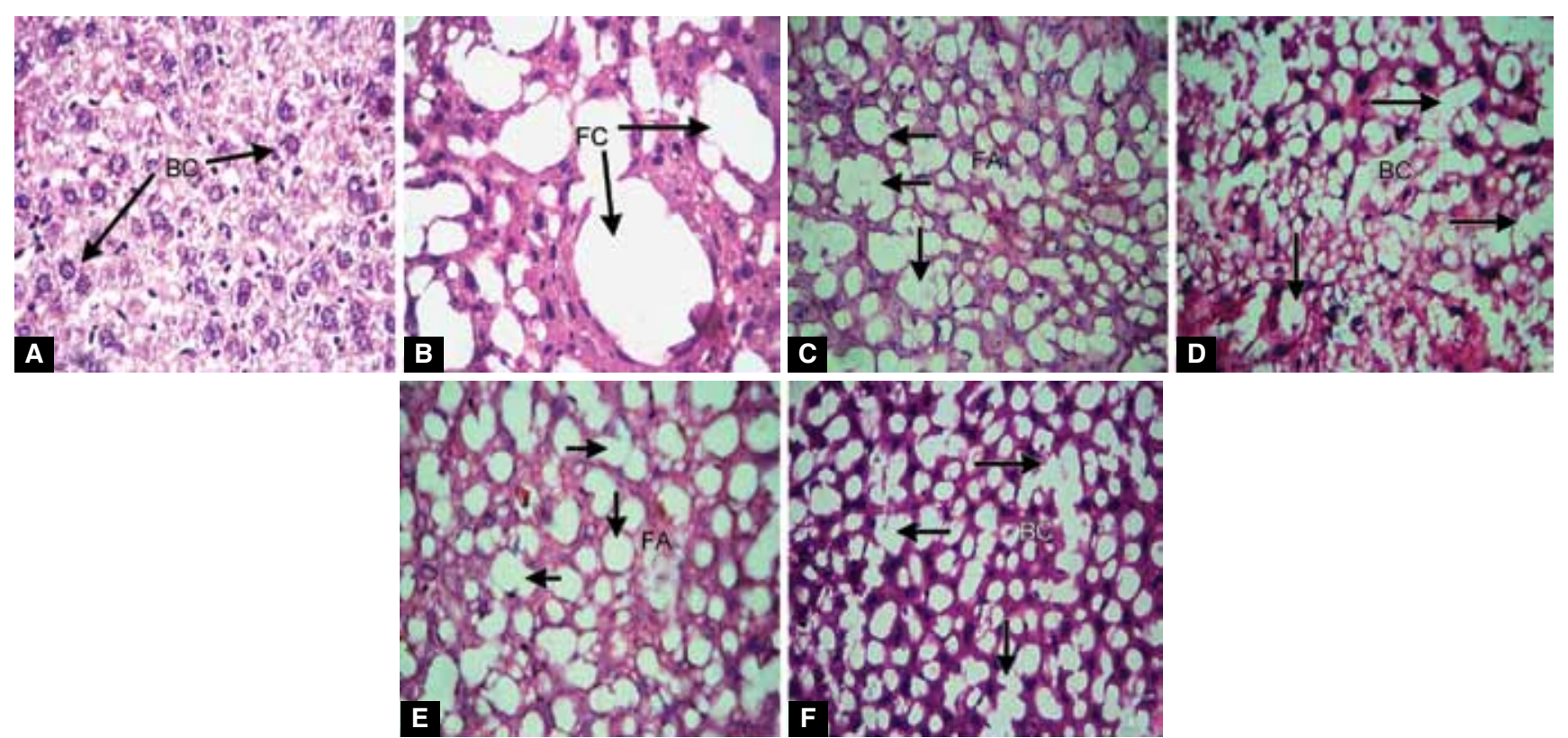

Figs 4A to F: Microscopic evaluation of tissue morphology of $\mathrm{HgCl}_{2}$-induced Hepatotoxicity in mice. (A) Saline control-treated group exhibits normal hepatocyte; (B) $\mathrm{HgCl}_{2}(5.0 \mathrm{mg} / \mathrm{kg})$ induced toxicity shows elevation of abnormal fat cyst formation; (C) EMI (25 mg/kg) combined with $\mathrm{HgCl}_{2}$ exhibits recovery of normal hepatocyte; (D) EMI $(50 \mathrm{mg} / \mathrm{kg})$ induced with $\mathrm{HgCl}_{2}$ shows significant recovery of normal hepatocyte; (E) $\mathrm{HgCl}_{2}$ treated with $\mathrm{MMI}(25 \mathrm{mg} / \mathrm{kg})$ elicits recovery of liver cells; $(\mathrm{F}) \mathrm{MMI}(50 \mathrm{mg} / \mathrm{kg})$ administered with $\mathrm{HgCl}_{2}$ shows significant recovery of normal hepatocyte with reduced formation of fat cyst formation. (BC- Bi-nucleated cells, FC- fat cyst formation and FA- fat accumulation)

\section{Histopathological Findings}

Histological changes in liver sections of control and experimental mice were shown in Figures 4A to F. The liver section of control mice displayed normal hepatocyte with negative signs of cellular abnormality (Fig. $4 \mathrm{~A}) . \mathrm{HgCl}_{2}$ alone intoxicated mice $(5.0 \mathrm{mg} / \mathrm{kg})$ shows conventional degeneration of cellular necrosis, massive inflammation and fat cyst formation (Fig. 4B). When compared with mercuric chloride alone intoxicated groups, the liver sections of EMI and MMI leaf (25 mg and $50 \mathrm{mg} / \mathrm{kg}$ ) extracts exhibited revival of normal cells upon necrotic damage in liver cells (Figs 4C and D). However, significant recovery of liver cell damage was observed in $\mathrm{HgCl}_{2}+\mathrm{MMI}(50 \mathrm{mg} / \mathrm{kg})$ extract-treated mice (Figs $4 \mathrm{E}$ and $\mathrm{F}$ ) as compared with the $\mathrm{HgCl}_{2}+$ EMI leaf extract $(50 \mathrm{mg} / \mathrm{kg})$.

\section{DISCUSSION}

Hepatocytes not only act as a prime target in eliminating the exogenous toxic substances by process of detoxification, also provides an excellent biomarker for diagnosis. Our investigation outlines the hepatoprotective effect of EMI and MMI leaf extract through its radical scavenging property against $\mathrm{HgCl}_{2}$-induced intoxication in hepatocyte of mice. Toxicity with $\mathrm{HgCl}_{2}$ can amend the biochemical changes through oxidative stress mediated cell injury by lipid peroxidation and also inactivate the cellular radical scavenging enzymes in liver such as catalase, glutathione peroxidase and glutathione s-transferase. Usually, antioxidant enzymes have the affinity to act as a primary scavenging intermediate of ROS. Hence, an increased level of ROS induces oxidative stress, resulting in the disturbance of prooxidant and simultaneously decreased the antioxidant enzyme levels due to over utilization to scavenge the products of ROS at the site of cell damage. ${ }^{20}$

In this study, we observed that the administration of $\mathrm{HgCl}_{2}$ in mice shows a much significant increase in the tissue aspartate transaminase and alanine transaminase levels, whereas significantly reduced level of enzymes were observed in normal mice. Elevated levels of tissue aspartate transaminase and alanine transaminase enzymes point out the abnormal functions of liver, due to cellular necrosis and increased membrane permeability. Hence, increase in porosity of cell membrane act as an open channel for the passage of intracellular enzymes to adjacent cells and the circulating blood. ${ }^{21}$ Other reports suggest that $\mathrm{HgCl}_{2}$ intoxication affect the amino acid transporter site in ribosomal subunits, this will lead to gradual decrease in plasma protein level. In our findings, combined treatment with plant extracts showed a significant decline in tissue aspartate transaminase and alanine transaminase enzyme levels when compared to $\mathrm{HgCl}_{2}$-induced mice, similar studies highlight that treatment using herbal remedies practiced for liver injury will significantly decrease the tissue aspartate transaminase and alanine transaminase levels. ${ }^{22}$

Glutathione s-transferase and catalase are the former defense systems which act mutually against ROS. An isoenzyme family of glutathione s-transferase binds to elec- 
trophilic compounds in conjugation with glutathione as a cofactor thereby elicits its cytoprotection against ROS. ${ }^{23}$ Catalase an antioxidant protective enzyme that scavenge the free radicals produced during toxicity. Increase in $\mathrm{OH}^{-}$ production in subcellular region inactivates enzyme activity and thereby causes tissue damage by lipid peroxidation. ${ }^{24}$ Investigators have shown that it may due to over exploitation to scavenge the products of lipid peroxidation. ${ }^{25}$ Administration of MI leaf extracts prior to $\mathrm{HgCl}_{2}$ induction significantly reduces the toxicity by increasing the level of glutathione s-transferase and catalase enzymes. When compared with the EMI extract treatment, MMI extract elicits better scavenging property. The histomorphological consequence of $\mathrm{HgCl}_{2}$ treated mice shows abnormal fat cyst formation followed by nucleoli pushed to the peripheral region in liver of mice, whereas administration of EMI and MMI extracts induced with $\mathrm{HgCl}_{2}$ showed prominent recovery of hepatocyte. However, MMI extract exhibits maximum transformation of damaged cells into normal cells. Hence, our obtained results suggest that supplementation of MI extract prevents free radical-induced oxidative events when intoxicated with $\mathrm{HgCl}_{2}$.

\section{CONCLUSION}

This study suggests that oral administration of MI extract acts as an effective radical quencher by augmenting the levels of antioxidant enzymes and guards the cells from lipid peroxidation. Tissue morphological signs also confer its protective effect against $\mathrm{HgCl}_{2}$ intoxication. Further experimental studies at molecular approach will be required to establish the effective action of the drug, which might be developed as a potent chemotherapeutic agent to treat liver disorders.

\section{ACKNOWLEDGMENTS}

The authors would like to extend sincere thanks to the financial grant supported by the University Grant CommissionNON-SAP/018692/2011 and Department of Biotechnology, Periyar University.

\section{REFERENCES}

1. Al-Othman ZA, Inamuddin, Naushad M. Determination of ion-exchange kinetic parameters for the poly-o-methoxyaniline $\mathrm{Zr}$ (IV) molybdate composite cation-exchanger. Chem Eng J 2011;166(2):639-645.

2. Grotto D, Valentini J, Fillion M, Passos CJ, Garcia SC, Mergler D, Barbosa F Jr. Mercury exposure and oxidative stress in communities of the Brazilian Amazon. Sci Total Environ 2010 Jan 15;408(4):806-811.

3. Mohamed ET, Mahran HA, Mahmoud MS. Hepato Ameliorative Effect of Azadirachta indica leaves extract against mercuric chloride environmental pollution. J Am Sci 2010;6(9):735-751.
4. Durak D, Kalender S, Uzun FG, Demir F, Kalender Y. Mercury chloride-induced oxidative stress in human erythrocytes and the effect of vitamins $\mathrm{C}$ and $\mathrm{E}$ in vitro. Afr J Biotechnol 2010;9(4): 488-495.

5. Sarma AD, Mallick AR, Ghosh AK. Free radicals and their role in different clinical conditions: An overview. Int J Pharma Sci Res 2010;1(3):185-192.

6. Ross IA. Medicinal plants of the world: Chemical constituents, traditional and modern medicinal uses $(\mathrm{M})$. New Jersey: Humana Press Inc; 2005. p. 43-53.

7. Ramesh PR, Parasuraman S, Vijaya C, Girish D, Devika GS. Antidiabetic effect of kernel seeds extract of Mangifera indica (Anacardiaceae). Int J Pharma Bio Sci 2011;2(1):385-393.

8. Pourahmad J, Eskandari MR, Shakibaei R, Kamalinejad M. A search for hepatoprotective activity of fruit extract of Mangifera indica L. against oxidative stress cytotoxicity. Plant Foods Hum Nutr 2010 Mar;65(1):83-89.

9. Rodeiro I, Hernandez S, Morffi J, Herrera JA, Gómez-Lechón MJ, Delgado R, Espinosa-Aguirre JJ. Evaluation of genotoxicity and DNA protective effects of mangiferin, a glucosylxanthone isolated from Mangifera indica L. stem bark extract. Food Chem Toxicol 2012 Sep;50(9):3360-3366.

10. Daud NH, Aung CS, Hewavitharana AK, Wilkinson AS, Pierson JT, Roberts-Thomson SJ, Shaw PN, Monteith GR, Gidley MJ, Parat MO. Mango extracts and the mango component mangiferin promote endothelial cell migration. J Agric Food Chem 2010 Apr 28;58(8):5181-5186.

11. Rajan S, Suganya H, Thirunalasundari T, Jeeva S. Antidiarrhoeal efficacy of Mangifera indica seed kernel on Swiss albino mice. Asian Pac J Trop Med 2012 Aug;5(8):630-633.

12. Garcia-Rivera D, Delgado R, Bougarne N, Haegeman G, Berghe WV. Gallic acid indanone and mangiferin xanthone are strong determinants of immunosuppressive anti-tumour effects of Mangifera indica L. bark in MDA-MB231 breast cancer cells. Cancer Lett 2011 Jun 1;305(1):21-31.

13. Singh SK, Tiwari RM, Sinha SK, Danta CC, Prasad SK. Antimicrobial evaluation of mangiferin and its synthesized analogues. Asian Pac J Trop Biomed 2012;2(2):S884-S887.

14. Liyana-Pathirana CM, Shahidi F. Antioxidant activity of commercial soft and hard wheat (Triticum aestivum L.) as affected by gastric $\mathrm{pH}$ conditions. J Agric Food Chem 2005 Apr 6; 53(7):2433-2440.

15. Bergmeyer, HU.; Bernt, E. Glutamate-pyruvate transaminase, UV-assay, manual method. In: Bergmeyer, HU., editor. Methods of enzymatic analysis. Vol. 2. New York: Academic Press; 1974. p. $752-758$.

16. Lowry OH, Rosebrough NJ, Farr AL, Randall RJ. Protein measurement with the Folin phenol reagent. J Biol Chem 1951 Nov;193(1):265-275.

17. Rotruck JT, Pope AL, Ganther HE, Swanson AB, Hafeman DG. Selenium: biochemical role as a component of glutathione peroxidase. Science 1973 Feb 9;179(4073):588-590.

18. Habig WH, Pabst MJ, Jakoby NB. Glutathione S-transferases. The first enzymatic step in mercapturic acid formation. J Biol Chem 1974 Nov 25;249(22):7130-7139.

19. Luck, H. Catalase. In: Bergmeyer, HU., editor. Methods in enzymatic analysis. New York: Academic Press; 1965. p. 885894.

20. Barcelos GR, Angeli JP, Serpeloni JM, Grotto D, Rocha BA, Bastos JK, Knasmüller S, Júnior FB. Quercetin protects human-derived liver cells against mercury-induced DNA- 
damage and alterations of the redox status. Mutat Res 2011 Dec 24;726(2):109-115.

21. Esmaeili AH, Khavari-Nejad RA, Hajizadehmoghaddam A, Chaichi M, Ebrahimzadeh M. Effects of eriobotrya japonica (Lindl.) flower extracts on mercuric chloride-induced hepatotoxicity in rats. Chin Sci Bull 2012;57:3891-3897.

22. Ung CY, Lam SH, Hlaing MM, Winata CL, Korzh S, Mathavan $\mathrm{S}$, Gong Z. Mercury-induced hepatotoxicity in zebrafish: in vivo mechanistic insights from transcriptome analysis, phenotype anchoring and targeted gene expression validation. BMC Genomics 2010 May 1;11:212.
23. He C, Fan X, Chen R, Liang B, Cao L, Guo Y, Zhao J. Osteopontin is involved in estrogen-mediated protection against diethylnitrosamine-induced liver injury in mice. Food Chem Toxicol 2012 Aug;50(8):2878-2885.

24. Rose S, Melnyk S, Pavliv O, Bai S, Nick TG, Frye RE, James SJ. Evidence of oxidative damage and inflammation associated with low glutathione redox status in the autism brain. Transl Psychiatry 2012 Jul 10;2:e134.

25. Deng Y, Xu Z, Liu W, Yang H, Xu B, Wei Y. Effects of lycopene and proanthocyanidins on hepatotoxicity induced by mercuric chloride in rats. Biol Trace Elem Res 2012 May;146(2):213-223. 